\title{
USING AUDIO-LINGUAL METHOD TO IMPROVE THE STUDENTS' SPEAKING SKILL
}

\author{
(A Classroom Action Research at the Fifth Grade of Madigondo \\ Elementary School in the Academic Year of 2015/2016)
}

\section{Eda Maaliah, Yulius Harry Widodo, and Muhyiddin Aziz Politeknik Negeri Madiun, Indonesia}

\begin{abstract}
Language teachers play an important roles on teaching and learning process, choosing the methods, and designing the goal of the study. All their targets are based on how well they collaborate the methods and designs through the experiences and knowledge they have during the process of teaching and learning. Audio-lingual method was chosen to know the effectiveness, advantages, disadvantages, strenghts, and weaknesses in improving the speaking skill of the fifth grade students of elementary school. The qualitative and quantitative data were used in this research. Qualitative data were taken from the scores of the pre-test and all cycles. The quantitative data were taken through the observation, interview, and questionnaire. Based on the discussions and conclusions, audio-lingual method is recommended to improve the speaking skill of elementary students.
\end{abstract}

Key words: audio-lingual method, speaking skill, teaching learning process

\section{Introduction}

The development of communication using international languages in oral or spoken grows fast in some aspects such as technology, economy, and education. First, Technology offers many kinds of facilities in communication such as internet, face book, twitter, e-mail, and soon. Second, Indonesia is on Asian economy community ( MEA ) started in 2016. 
Third, Education provides competitive standard that must be reached as the requirement of graduation. They force all of the level and age of people to understand the international languages approximately English.

Elementary Students, as young generations or the beginners of language, need to be communicatively competent in English. It means that they need to study hard to master the four language skills in passive and active way namely listening, speaking, reading, and writing.

Speaking is an active language action from the language users that demand the real initiation in language employing to express self orally. It is very important for the students of elementary school as they can be classified as the beginner of English user.

In fact, the students of elementary school have limited vocabularies. They get difficulty to choose the verbs that they want to express their idea. Some of them do not understand some structures well. They get difficulty to arrange words or sentences that causes wrong sentences. The others get some problems in pronunciation so that listeners get difficulty to understand they mean and even misunderstand their expression. They also feel ashamed in using English to communicate with their friends moreover with their teacher because they are afraid of making mistakes or considered as a pride and show-off students.

There are some aspects of teaching which can influence students' speaking skills. They are teacher, and method. A good method brings the significant influence in the success of the process of teaching learning, especially in terms of improving students' speaking skill in the class. So, the effective way should be applied by the teacher in achieving class objectives.

To help the teacher in teaching speaking for elementary students, teacher should use an easy method which can guide them during teaching and learning process. The teacher also should create a relax situation which is not burden the students. He can use a method which is started by full guidance before he lets the students practice it and comes to the next phase which motivates them to create and express their own opinion in good English such as arranging, choosing, and pronouncing words, and organizing sentences.

The Audio-lingual Method is another way of teaching used in teaching foreign languages. According to Richards and Rodgers,Audio-lingual Method is a method of foreign or second language teaching which 
emphasizes the teaching of speaking and listening before reading and writing. That is why mother tongue is discouraged in the class of Audiolingual Method. The method is based on behaviourist theory whichis used to train humans through a system of reinforcement. It is closely tied tobe haviourism, and thus made drilling, repetition, and habit-formation central elements of instruction (2001: 66).

\section{Literature Review}

Speaking is the second skills among the four skills that should be comprehended by the people chronologically in their life. It is also one of the language arts that is very complex used by people all over the world. That is why, people should learn and practise the ability of speaking skills to master it. Nunan (2000: 39) states that the art of speaking is the single most important aspect of learning second or foreign language, and success is measured in terms of the ability to carry out a conversation in the language. Bygate (2000: 5) states that students must be good in speaking skill which involves: choosing the right form, putting them in the correct order, sounding like a native speaker, and even producing the right meanings.

Furthermore, Syakur (1987: 3) states that there are, generally, at least four components of speaking skill: comprehension, grammar, vocabulary, pronunciation, and fluency.

1. Comprehension. Oral communication certainly requires a subject to respond to speech as well as to initiate it.

2. Grammar. It is needed for students to arrange a correct sentence in conversation, and to distinguish appropriate grammatical form in appropriate ones. The utility of grammar is also used to learn the correct way to gain expertise in a language in oral and written form.

3. Vocabulary. One cannot communicate effectively and express their ideas both orally and in written form if they do not have sufficient vocabulary. So vocabulary means the appropriate diction which is used in communication.

4. Pronunciation. Pronunciation is the way students produce clearer language when they speak. It deals with phonological process that refers to the component of a grammar made up of the elements and principles that determine how sounds vary and pattern in language. 
5. Fluency. Signs of fluency include a reasonably fast speed of speaking and only a small number of pauses. These signs indicate that the speaker does not spend a lot of time searching for the language items.

Teaching speaking is a crucial part of second language learning and teaching. Despite its importance, for many years, teaching speaking has been undervalued and English language teachers have continued to teach speaking just as a repetition of drills or memorization of dialogues. However, today's world requires that the goal of teaching speaking should improve students' communicative skills, because, only in that way, students can express themselves and learn how to follow the social and cultural rules appropriate in each communicative circumstance (Nunan, in Kayi, 2006: 3). The skill of communication in a second language clearly and efficiently contributes to the success of the learner in school and success later in every phase of life. Therefore, it is essential that language teachers pay great attention to teach speaking rather than lead students to pure memorization, providing a rich environment where meaningful communication takes place is described. With this aim, various speaking activities can contribute a great deal to students in developing basic interactive skills necessary for life. These activities make students more active in the learning process and at the same time make their learning more meaningful, fun and communicative.

Communicative language teaching and collaboration learning serve best the student to learn to speak in the foreign language by interacting. Communicative language teaching is based on real-life situation that requires communication. It will give students more opportunity to communicate each other using the foreign language. Teacher should be able to create a classroom environment where students have real-life communication, authentic activities, and meaningful task that promote oral language. This can occur when students collaborate in groups to achieve a goal or to complete a task (Nunan, in Kayi, 2006: 2).

Richards and Rodgers (2001: 50) state that Audio-lingual Method is a method of foreign or second language teaching which emphasizes the teaching of speaking and listening before reading and writing. It uses dialogues as the main form of language presentation and drills as the main training techniques and mother tongue is discouraged in the classroom. It is also named the aural-oral method, or mim-mem method because the method uses exercises such as pattern practice dialogues which make use of the 
mimicry (imitation) and memorization of material presented as a model. Furthermore, Larsen (2000: 35) adds that the Audio-lingul Method is a method drilling students in the use of grammatical patterns based on a strong theory in linguistics and psychology. Brooks (1964: 50) states that recognition and descrimination are followed by imitation, repetition and memorization. Only when he is thoroughly familiar with sounds, arragements, and forms does he center his attention on enlarging his vocabulary.

Louma (2004: 59) states that speaking scores express how well the examinees can speak the language being tested. They usually take the form of numbers, but they also be verbal categories such as 'excellent' or 'fair' . Scale for assessing speaking must always be related to the purpose of the test and the definition of the construct to be assessed.

Gottlieb (1995: 17) states that the following scoring rubric is used to analyze and evaluate group or pairs activities test. It is also simple scoring rubric which is suitable to hold class action research especially on speaking. The total score will be multiplied by four to gain the score result of the test. 
Table 1 the Scoring Rubric

\begin{tabular}{|c|c|c|c|c|c|}
\hline Indicators & 1 & 2 & 3 & 4 & 5 \\
\hline Comprehension & $\begin{array}{l}\text { Cannot understand } \\
\text { even simple } \\
\text { conversation }\end{array}$ & $\begin{array}{l}\text { Has great difficulty } \\
\text { following what is said. } \\
\text { Can comprehend only } \\
\text { "social conversation" } \\
\text { spoken slowly and } \\
\text { with frequent } \\
\text { repetitions. }\end{array}$ & $\begin{array}{l}\text { Understands most of } \\
\text { what is said at slower- } \\
\text { than-normal speed with } \\
\text { repetitions. }\end{array}$ & $\begin{array}{l}\text { Understands nearly } \\
\text { everything at } \\
\text { normal speed } \\
\text { although occasional } \\
\text { repetition may be } \\
\text { necessary. }\end{array}$ & $\begin{array}{l}\text { Understands everyday } \\
\text { conversation and normal } \\
\text { classroom discussions } \\
\text { without difficulty. }\end{array}$ \\
\hline Fluency & $\begin{array}{l}\text { Speech is so halting } \\
\text { and fragmentary as to } \\
\text { make conversation } \\
\text { virtually impossible. }\end{array}$ & $\begin{array}{l}\text { Usually hesitant; often } \\
\text { forced into silence by } \\
\text { language limitations. }\end{array}$ & $\begin{array}{l}\text { Speech in everyday } \\
\text { conversation and } \\
\text { classroom discussions } \\
\text { frequently disrupted by } \\
\text { the student's search for } \\
\text { the correct manner of } \\
\text { expression. }\end{array}$ & $\begin{array}{l}\text { Speech in everyday } \\
\text { conversation and } \\
\text { classroom } \\
\text { discussions } \\
\text { generally fluent, } \\
\text { with occasional } \\
\text { lapses while the } \\
\text { student searches for } \\
\text { the correct manner } \\
\text { of expression. }\end{array}$ & $\begin{array}{l}\text { Understands everyday } \\
\text { conversation and } \\
\text { classroom discussions } \\
\text { fluent and effortless, } \\
\text { approxima- tely that of a } \\
\text { native speaker. }\end{array}$ \\
\hline Vocabulary & $\begin{array}{l}\text { Vocabulary } \\
\text { limitations so } \\
\text { extreme as to make } \\
\text { conversation virtually } \\
\text { impossible. }\end{array}$ & $\begin{array}{l}\text { Misuse of words and } \\
\text { very limited } \\
\text { vocabulary: } \\
\text { comprehension quite } \\
\text { difficult. }\end{array}$ & $\begin{array}{l}\text { Student frequently uses } \\
\text { the wrong words: } \\
\text { conversation somewhat } \\
\text { limited because of in } \\
\text { adequate vocabulary. }\end{array}$ & $\begin{array}{l}\text { Student } \\
\text { occasionally uses } \\
\text { inappropri-ate } \\
\text { terms and/or must } \\
\text { rephrase ideas } \\
\text { because of lexical } \\
\text { inadequacies. }\end{array}$ & $\begin{array}{l}\text { Use of vocabulary and } \\
\text { idioms approximate that } \\
\text { of a native speaker. }\end{array}$ \\
\hline
\end{tabular}




\begin{tabular}{|c|c|c|c|c|c|}
\hline Pronuncia-tion & $\begin{array}{l}\text { Pronunciation } \\
\text { problems so severe as } \\
\text { to make speech } \\
\text { virtually impossible. }\end{array}$ & $\begin{array}{l}\text { Very hard to } \\
\text { understand because of } \\
\text { pronunciation } \\
\text { problems. Must } \\
\text { frequently repeat in } \\
\text { order to make himself } \\
\text { or herself understood. }\end{array}$ & $\begin{array}{l}\text { Pronunciation problems } \\
\text { necessitate concentration } \\
\text { on the part of the listener } \\
\text { and occasionally lead to } \\
\text { misunderstanding. }\end{array}$ & $\begin{array}{l}\text { Always intelligible, } \\
\text { though one is } \\
\text { conscious of a } \\
\text { definite accent and } \\
\text { occasional } \\
\text { inappropri-ate } \\
\text { intonation patterns. }\end{array}$ & $\begin{array}{l}\text { Pronuncia-tion and } \\
\text { intonation approximate } \\
\text { that of a native speaker. }\end{array}$ \\
\hline Grammar & $\begin{array}{l}\text { Errors in grammar } \\
\text { and word order } \\
\text { severe as to make } \\
\text { speech virtually } \\
\text { intelligible. }\end{array}$ & $\begin{array}{l}\text { Grammar and word- } \\
\text { order errors make } \\
\text { comprehension } \\
\text { difficult. Must often } \\
\text { rephrase and/or restrict } \\
\text { himself or herself to } \\
\text { basic patterns. }\end{array}$ & $\begin{array}{l}\text { Makes frequent errors of } \\
\text { grammar and word-order } \\
\text { which occasionally } \\
\text { obscure meaning. }\end{array}$ & $\begin{array}{l}\text { Occasionally makes } \\
\text { grammatical and/or } \\
\text { word-order errors } \\
\text { which do not } \\
\text { obscure meaning. }\end{array}$ & $\begin{array}{l}\text { Grammatical usage and } \\
\text { word-order approximate } \\
\text { that of a native speaker. }\end{array}$ \\
\hline
\end{tabular}




\section{Research Methodology}

The research applies Classroom Action Research (CAR). Harmer (2003: 414) states that Action Research is the name given to a series of procedures teacher can engage in, perhaps because they wish to improve aspects of their teaching, or alternatively, because they wish to evaluate the success and/or appropriation of certain activities and procedures.

Action research is described as a spiral steps and there are four stages: planning, acting, observing, and reflecting (Lewis in McNiff, 1998: 22). In conducting this research, the design procedure will be adapted to other kind to fit the overall condition of this research. Basically the design consists of the four components as the one Lewin has.
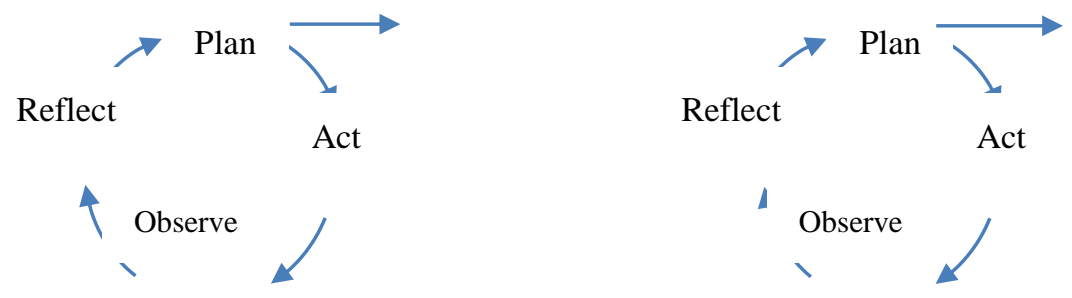

There are two kinds of data which are used in this research, the quantitative and qualitative data. The quantitative data are in the form of students' scores. The data are students' scores from the beginning of the research to the end of the research. They are taken from the test. The qualitative data are collecting by the following techniques: observations, questionnaires, and interviews.

\section{Research Finding}

The students of the fifth grade of SDN Madigondo preferred using Indonesian and Javanese to communicate with their friends. They practised their English when the teacher reminded them. They used English on simple communication or short conversation. They seemed lazy and bored to practise their English.

In pre survey on Friday March $4^{\text {th }}, 2016$ in answering the questions, some students replied in the short answer. The others preferred using Indonesian or Javanese to English as they could speak fluently. They also thought that speaking English was difficult and unexpressed well. 
The researcher found the problems through the interview, questionnaire, and observation. The problem also based on the pre-test on Saturday March $5^{\text {th }}$ 2016, and friday March $11^{\text {th }}, 2016$. The researcher used some blanks in the dialogs and the students tried to fulfill. The teacher drilled the students by using that dialong. Some students could not fulfill by using vocabularies given. The teacher asked them to practise and come forwards. Some students could not pronounce some words, slow in expressing and event silent in front of the class. In short, It could be concluded that the students had some problems on comprehension, fluency, vocabulary, pronunciation, and grammar.

After finishing all the steps of the cycles, the researcher designed the goal of the research such as the students were able to;

1. Comprehend on their topics.

2. Use the correct words.

3. Choose the correct structures.

4. Speak in the correct intonation, stress, and pronunciation.

5. Deliver their sentences fluently.

Research Implementation

1. Cycle I

It had been stated that the fifth grade students of SDN Madigondo got some problems on speaking. They faced the problem on comprehension, fluency, vocabulary, pronunciation, and grammar. The suitable method chosen was audio-lingual method. It was used to make the goal of the research come true. The first cycle was used to describe the process of teaching and learning by using audio-lingual method in order to improve the students' skill on speaking. It was done in four steps such as; 1) planning; 2) acting; 3) observing; and 4) reflecting.

a. Planning

In this step, the researcher planned the lesson plans in order to achieve the goal. Audio-lingual method was chosen as the way to bring the students get out of their daily activity of the curriculum. It was chosen as it could make the students learn English especially on speaking in the relax situation. The lesson plans were as follows: 1) designing the indicators achieved; 2) choosing the activities, dialog memorization and grammar 
game; 3) using some dialogs in the blank spaces; 4) arranging the students' task; and 5) designing spoken assessment.

b. Acting

The action was done for four meetings. The first meeting, the researcher discussed about the pattern and the usage of simple present on full verb and linking verb version. The second meeting, the researcher explained the use of simple present in a dialog. The third meeting the researcher explained and gave examples to fulfill the blanks in the dialog using simple present. In the fourth meeting, the researcher invited all the students to perform the descriptions in group in front of the class.

c. Observing

The observation was aimed to know the influence of the method applied during the process of teaching and learning. The observation consisted of three phases such as observing the class during Audiolingual method; interviewing the students after practicing Audiolingual method; and holding spoken test to know the improvement of the speaking indicators.

d. Reflecting

In the cycle I, the students said that the activities of drilling dialogs motivated them to learn English more especially on speaking. They felt that it was easy to practise English as it was full of teacher guidance. The students also felt comfortable as they could learn while practising under the control of the guidance of the teacher.

2. Cycle II

The students faced some difficulties in repeating some pronunciation, choosing words and arranging words into sentences in fulfilling the blank of the dialogs during the first cycle. The researcher continued the research to the second cycle which consisted of: 1) revised planning; 2) acting; 3) observing; and 4) reflecting.

a. Revised planning

Some students faced some difficulties in memorizing some difficult words, and arranging them into sentences while the others were on pronouncing some words during audio-lingual Method. The researcher made the lesson plans to solve the problems. They were as follows: 1) designing the indicators achieved; 2) choosing the activities, repitition drill, and Chain drill; 3) using some dialogs; 4) arranging the students' task; and 5) designing spoken assessment. 


\section{a. Acting}

The action was done for four meetings which were based on the revised planning. The first meeting, the researcher discussed about the way in choosing the suitable words based on the function and category and pronouncing them correctly. The second meeting, the researcher explained the way to arrange the words with the different category and function into sentences. The third meeting the researcher explained the way in arranging sentences to fullfil the blanks of the dialogs. In the fourth meeting, the researcher gave opportunities to all the students to show their ability of communication based on the dialogs in front of the class.

b. Observing

The observation was aimed to know the influence of the method applied during the process of teaching and learning. The observation consisted of three phases such as observing the class during Audiolingual method; interviewing the students after practicing Audiolingual method; and holding spoken test to know the improvement of the speaking indicators among the students.

c. Reflecting

The students said that the activities of Audiolingual method, repitition drill, and Chain drill, in the cycle II motivated them to learn English more especially on speaking. They felt that it was easy to practise English as it was full of teacher guidance. The students also felt comfortable as they could learn while practising under the control of the guidance of the teacher.

\section{Cycle III}

Based on the evaluation of the second cycle, the researcher found some students made mistakes on structure during arranging words into sentences especially the differences between statement and interrogative, and interrogative and question words. The researcher continued the research to the third cycle which consisted of: 1) revised planning; 2) acting; 3) observing; and 4) reflecting.

a. Revised planning

Some students faced some difficulties in using different structures of statement and interrogative, interrogative and question words. The researcher made the lesson plans to solve the problems. They were as follows: 1) designing the indicators achieved; 2) choosing the activities, Structure in 
dialogs and question and answer drill; 3) using some blanks in the dialogs in consist of the different usage of structure; 4) arranging the students' task; and 5) designing spoken assessment.

b. Acting

The action was done for four meetings which were based on the revised planning. The first meeting, the researcher reminded the different structures of statement and interrogative, interrogative and question words. The second meeting, the researcher explained the use of the structure in the sentences of the dialogs and gave many examples. The third meeting the researcher drilled the students in using the structures in spoken skill. In the fourth meeting, the researcher gave opportunities to all the students to show their ability of communication based on the dialogs in front of the class.

c. Observing

The observation was aimed to know the influence of the method applied during the process of teaching and learning. The observation consisted of three phases such as observing the class during audio-lingual method; interviewing the students after practicing audio-lingual method; and holding spoken test to know the improvement of the speaking indicators.

d. Reflecting

The students said that the activities of audio-lingual method, structure in dialogs and question and answer drill, in the cycle III motivated them to learn English more especially on speaking. They felt that it was easy to practise English as it was full of teacher guidance. The students also felt comfortable as they could learn while practising under the control of the guidance of the teacher.

Based on the research finding, there were some important points of the improvements that could show the target of the research. They were the improvement of: 1) comprehension; 2) fluency; 3) vocabulary; 4) pronunciation; 5) grammar; 6) the strengths and weakness of communication games. The classifications are as follows:

1. The Improvement of Students Speaking Skill

The observation of cycle 1, 2, and 3 showed the indicators of speaking improvement during teaching and learning process. The proofs of the improvement were on: 1) comprehension. Most of the students could response their friends during applying audio-lingual method; 2) fluency. Some students could deliver their sentences and expression in the dialogs 
fluently; 3) vocabulary. Most of the students could choose the words to fullfil the blank of the different dialogs; 4) pronunciation. Most of the students could pronounce the words well in good intonation and stress; 5) grammar. Some students can use the basic structures in fulfilling the dialogs and practising them during the class using audio-lingual method.

The students speaking scores improved from cycle to cycle which is shown in the following tables.

Table 2 the score of pre-test and post-tests

\begin{tabular}{|c|l|c|c|c|c|}
\hline No & \multicolumn{1}{|c|}{ Level } & Pre-test & Post-test & Post-test & Post-test \\
\hline 1. & Highest & 76 & 80 & 84 & 88 \\
\hline 2. & Average & 64 & 68 & 70 & 72 \\
\hline 3. & Lowest & 60 & 64 & 68 & 68 \\
\hline
\end{tabular}

Table 3 The students' passing grade

\begin{tabular}{|c|c|c|c|c|c|c|}
\hline \multirow{2}{*}{ No } & Passing & \multirow{2}{*}{ The students' score } & \multicolumn{4}{|c|}{ The sum of students } \\
\cline { 4 - 7 } & grade & & Pre-test & Cycle II & Cycle II & Cycle III \\
\hline 1. & 70 & Above Passing Grade & 7 & 9 & 10 & 11 \\
\hline 2. & 70 & Under Passing Grade & 5 & 3 & 2 & 1 \\
\hline
\end{tabular}

2. The strengths and the Weaknesses of Audio-lingual Method

The application of audio-lingual method from cycle to cycle showed the strengths such as: 1) balancing the ability. It made the students gather in the same situation. So that there is no differences between the fastest and slowest students; 2) interest. The students changed their perception that English was difficult. They also felt comfortable as the teacher guided them all the time during the theory of the subjects; 3) Teacher-centered. The students can focus only to a figure, teacher, during the class. The teacher also could manage and transfer the knowledge well as the method always invited the students to repeat what the teacher said.

Audio-lingual Method also had some weaknesses such as: 1) uncreative students. The students only follow the teacher and fullfil the blanks; 2) dependence. The students only relayed on the teacher. They were passive as they only practising the subject being transfered.

Conclusion

Audio-lingual method can improve the students speaking skill. The speaking skills such as comprehending the topics being communicated 
fluently; choosing the proper vocabularies for the blanks in the dialogs; pronouncing the words and expressing sentences in good intonation and pronunciation; and using the correct grammar stuctures during applying the audio-lingual method.

Audio-lingual method have many strengths that are useful for the students and the teachers. The teacher can transfer the knowledge with the full guidance that made the students comfortable. The teacher also can manage the class well as he became a centred-person.

Audio-lingual method is good to be used in teaching speaking, especially for the students of the fifth grade of SDN Madigondo. A teacher should use audio-lingual method to make the students able to speak english in safe and comfortable situation of the class. The teacher also should be able to manage the class as the students are classified as children so that there should be focus method to guide the students.

Audio-lingual Method also provide opportunities for students to master the materials well. For instance, on the first cycle, the students learn grammar through games and dialog memorization. The students fullfil the blanks in the dialogs basen on the different structures and vocabularies before practising them in a conversation in front of the class. During the activities, the students can consult their difficulty and their teacher explains and corrects all the mistakes during the activities so that the students understand the material and can use it correctly.

\section{References}

- $\quad$ Brooks, N. (1964). Language and Language Learning: Theory and Practice. 2nd. ed. New York: Harcourt Brace.

- $\quad$ Bygate, Martin. (2000). Speaking. Oxford: Oxford University Press.

- Harmer, Jeremy. (2003). The Practice of English Language Teaching. Malaysia: Pearson Education Limited.

- Larsen, Diane. (2000). Techniques and Principles in Language Teaching. Hong Kong: Oxford University Press.

- Luoma, Sari. (2005). Assessing Speking. Cambridge University press.

- Mc. Niff, Jean. (1988). Action Research: Principles and Practice, Mac Millan Education Ltd. 
- Nunan, David. (1998). Designing Tasks for the Communicative Classroom. London: Cambridge University Press.

$\bullet$ (1989). Designing Task for the Communicative Classroom. London: Cambridge University Press.

- $\quad$ (1998). Designing Tasks for the Communicative Classroom. London: Cambridge University Press.

- (2000). Language Teaching Methodology.

New York: Longman Pearson Education Inc.

- $\quad$ Richards, Jack C. and Rodgers, Theodore S. (2001). Approaches and Methods in Language Teaching. New York: Cambridge University Press.

- Syakur. (1987). Language Testing and Evaluation. Surakarta: Sebelas Maret University Press.

- Weir, Cyril J. (1990). Communicative Language Testing. New York: Prentice Hall 